\title{
Reakcje na sytuacje stresowe $w$ opinii pielęgniarek na oddziałach zabiegowych
}

\author{
Occupational stress reactions among nurses working \\ in surgical wards
}

IWONA CZARNIECKA1,2, DOMINIKA PODSIADŁY33, ROBERT ŚLUSARZ11,4

${ }^{1}$ Instytut Nauk o Zdrowiu PWSZ we Włocławku

2 Wojewódzki Szpital Specjalistyczny im. Bł. Ks. J. Popiełuszki we Włocławku

3 Oddział Pediatrii, Gastroenterologii, Kardiologii, Neurologii, Diabetologii i Endokrynologii, Regionalny Szpital Specjalistyczny im. Dr. W. Biegańskiego w Grudziądzu

4 Zakład Pielęgniarstwa Neurologicznego i Neurochirurgicznego, CM im. Ludwika Rydygiera w Bydgoszczy

DOI: http://dx.doi.org/10.21784/IwP.2018.020

ISSN: 2451-1846

\section{Streszczenie:}

Wstęp. Stres zawodowy jest zjawiskiem, które dotyka wielu osób pracujących zawodowo. Jest powszechnie uznawany jako efekt relacji między potrzebami pracownika i jego możliwościami,a wymaganiami jakie stawia środowisko.

Cel. Celem przeprowadzonych badań jest analiza strategii radzenia sobie ze stresem wśród pielęgniarek pracujących na oddziałach zabiegowych.

Materiał i metody. Badanie zostało przeprowadzone w grupie pielęgniarek i pielęgniarzy pracujących na oddziałach zabiegowych w Regionalnym Szpitalu Specjalistycznym im. dr W. Biegańskiego w Grudziądzu. Przed przystąpieniem do badań otrzymano zgodę Komisji Bioetycznej oraz Dyrekcji placówki. Narzędziami badawczymi w pracy był standaryzowany kwestionariusz MiniCope oraz kwestionariusz ankiety konstrukcji własnej.

Wyniki. Analiza wyników dowiodła, że za główne czynniki stresogenne w pracy najwięcej respondentów uznało roszczeniowość pacjentów oraz 
w takim samym stopniu na śmierć pacjentów i poczucie odpowiedzialności za drugą osobę. Jako czynniki stanowiące przypuszczalne źródło stresu i wypalenia zawodowego respondenci wskazało: złą organizację pracy, poczucie nieadekwatności wynagrodzenia do wykonywanej pracy oraz złą atmosferę $\mathrm{w}$ pracy. Respondenci $\mathrm{z}$ oddziału zabiegowego $\mathrm{w}$ radzeniu sobie ze stresem stosowali najczęściej strategię: aktywne radzenie sobie oraz style: aktywne radzenie sobie i akceptacja.

Wnioski. Zatrudnienie w oddziałach zabiegowych nie miało istotnego wpływu na wybór strategii i stylów radzenia sobie ze stresem przez pielęgniarki/pielęgniarzy.

Słowa kluczowe: stres, pielęgniarka, oddział zabiegowy

\section{Abstract:}

Introduction. Occupational stress is common among people professionally employed . It is related to the relationship between workers' needs and capacity as well as the requirements posed by the labour market.

Aim. The aim of the study was to analyse different strategies of dealing with occupational stress among nurses working in surgical wards.

Materials and methods. The study was carried out in a group of nurses working in surgical wards in dr Biegański Specialist Hospital in Grudziądz. The study was aproved by the Bioethics Committee and the management of the hospital. Standartised Mini-Cope questionnaire together with a questionnaire prepared by the researchers were used as study tools.

Results. The analysis proved that most respondents perceive patients' demanding attitude, the death of a patient as well as the sense of resposibility for a patient as the main stress factors.Wrong work organization , inadequate pay for the workload and bad working atmosphere represent potential source of stress and professional burnout. Active involvment in coping with stress and its acceptance were the strategies that the respondents used most often.

Conclusions. Work in the surgical wards had no significant effect on the choice of strategies and styles of coping with occupational stress.

Keywords: occupational stress, nurse, surgical ward 


\section{Wstęp}

Pojęcie stresu jest stosunkowo trudne do zdefiniowania, pomimo tego, iż doświadczamy go niemal codziennie w naszym życiu. Określenie „stres” wywodzi się z języka angielskiego od słowa „stress”. Stanowi ono jedno z bardziej znanych zagadnień psychologii, bowiem przypisuje się jemu odpowiedzialność za większość zaburzeń psychologicznych [1].

Koncepcje stresu według polskich autorów głównie nawiązują do jego psychologicznych uwarunkowań. Wśród nich należy wspomnieć o teorii sytuacji trudnych T. Tomaszewskiego. Przez taką sytuację autor rozumie rozbieżność między potrzebami lub zadaniami człowieka, tym jakie są możliwości ich zaspokojenia. Autor przypisał stres psychologiczny do definicji sytuacji trudnej. Ponadto wyróżnił kilka typów takiej sytuacji: przeciążenie, deprywację, utrudnienie oraz zagrożenie [2,3].

Stres jest wszechobecny, towarzyszy każdemu z nas. Niektórzy twierdzą, że stres jest elementem współczesnego świata [4].

Jeżeli mówimy o stresie to należy wspomnieć o potencjalnych źródłach (stresorach) tego zjawiska. Przez stresor należy rozumieć zewnętrzny lub wewnętrzny bodziec lub zdarzenie, które narusza względny spokój między środowiskiem, a podmiotem. Ze względu na istotę tak interpretowanego zjawiska źródła stresu możemy podzielić na biologiczne, fizyczne, społeczne oraz psychologiczne [3].

Jako fizyczne źródła zagrożenia stresu należy wymienić czynniki klimatyczne, poziom hałasu, stopień oświetlenia czy rodzaj promieniowania. Źródła stresu o podłożu biologicznym wiążą się z aktywnością i odpoczynkiem naszego organizm o określonych porach. Jeśli funkcjonowanie naszego organizmu $\mathrm{z}$ rytmem biologicznym jest zaburzone, wówczas jest to tzw. chronobiologiczny czynnik stresu. Kolejne czynniki psychologiczne stresu związane są z zakłóceniami, czy przeciążeniami jakie napotykamy w codziennym życiu. Chodzi tutaj głównie o nadmierne wymagania związane 
z wykonywaniem danej czynności, czy o zbyt duży wysiłek umysłowy bądź fizyczny. W modelu stresu psychologicznego wyróżnia się także zagrożenia zarówno fizyczne - choroba, utrata życia ale także społeczne takie jak kompromitacja przed współpracownikami, czy odpowiedzialność za życie innych. Z kolei wśród społecznych czynników stresu główne źródła stresu stanowi rodzina, która jest traktowana jako pierwotny stresor. Decyduje ona o poziomie relacji emocjonalnych jak i społecznych [2].

Stres zawodowy jest zjawiskiem, które dotyka wiele osób pracujących zawodowo. Jest powszechnie uznawany jako efekt relacji między potrzebami pracownika i jego możliwościami a wymaganiami jakie stawia środowisko [5,6]. Głównym źródłem stresu w pracy zawodowej pielęgniarki jest przede wszystkim presja czasu. Nieprzewidywalne sytuacje takie jak: reanimacja, nagłe pogorszenie się stanu chorego wymagają od pielęgniarki dużej odpowiedzialności i szybkości działania. Doprowadza to do obniżenia efektywności pracy a co za tym idzie $\mathrm{z}$ postępującym zmęczeniem. Stresującym czynnikiem $w$ pracy zawodowej pielęgniarki są także relacje z pacjentami, ich rodzinami czy nawet współpracownikami, które często z powodu narastającego napięcia emocjonalnego są źródłem stresu [7]. Powstawanie sytuacji stresogennych w pracy związane jest także $\mathrm{z}$ dysproporcją, pomiędzy wymaganiami jakie są stawiane pracownikom, a możliwościami indywidualnymi. Często wymagania są wyższe a niżeli możliwości. Związane jest to $\mathrm{z}$ brakiem kadry pielęgniarskiej w polskich szpitalach [8].

Obecnie wiele uwagi poświęca się zjawisku wypalenia zawodowego. Syndrom wypalonych sił, zwany też " ang. burt out" zaczął budzić zainteresowanie naukowców od dawna. W 1971r. kiedy to po raz pierwszy zjawisko zostało opisane przez psychiatrę H. Freudenbergera [2]. Autor określił wypalenie zawodowe jako: „krańcowy stan wyczerpania spowodowany nadmiernym zapotrzebowaniem na energię i wszelkie zasoby, jakimi dysponuje jednostka" [9]. 
Praca pielęgniarki postrzegana jest jako służba drugiemu człowiekowi, która utożsamiana jest ze źródłem zadowolenia, sympatii, jednak często też bywa przyczyną zniechęcenia, braku satysfakcji. Obecnie w naszym kraju mamy do czynienia z niedostatkiem kadr w grupie zawodowej pielęgniarek, często młode wykształcone pielęgniarki wyjeżdżają za granicę $\mathrm{w}$ poszukiwaniu lepszych zarobków. Sytuacja ekonomiczna, powoduje wzrost wymagań jeśli chodzi o personel. Często pielęgniarki pracują zbyt wiele godzin tygodniowo, co niestety negatywnie wpływa na sytuację rodzinną, stan ich zdrowia ale również na jakość wykonywanej pracy. Dochodzi wówczas do powstania syndromu wypalenia zawodowego $[10,11,12]$.

Celem przeprowadzonych badań jest analiza strategii radzenia sobie ze stresem wśród pielęgniarek pracujących na oddziałach zabiegowych.

\section{Materiał i metody}

Badanie zostało przeprowadzone $\mathrm{w}$ grupie pielęgniarek i pielęgniarzy pracujących na oddziałach zabiegowych w Regionalnym Szpitalu Specjalistycznym im. dr W. Biegańskiego w Grudziądzu, po uzyskaniu pozytywnej zgody Komisji Bioetycznej oraz zgody Dyrekcji szpitala.

Narzędziami badawczymi w pracy był standaryzowany kwestionariusz Mini-Cope oraz kwestionariusz ankiety konstrukcji własnej. Kwestionariusz dotyczył stresu oraz narażenia na wystąpienie wypalenia zawodowego.

Przed przystąpieniem do analizy baza danych została sprawdzona pod względem logiczności i kompletności odpowiedzi. Przyjęto hipotezę zerową $\left(\mathrm{H}_{0}\right)$, że nie ma różnicy w badanych grupach. Przyjęto również poziom istotności $\mathrm{p} \leq 0,05$ jako poziom istotny statystycznie. Wszystkie obliczenia i ryciny wykonano Statistica 10.0 i arkuszem kalkulacyjnym Microsoft Excel wykorzystując standardowe funkcje tego programu. 


\section{Wyniki}

Tabela 1. Grupy wiekowe badanych.

\begin{tabular}{|l|l|l|}
\hline grupa wiekowa & N & $\%$ \\
\hline $22-35$ lat & 14 & 36,8 \\
\hline $36-45$ lat & 9 & 23,7 \\
\hline $46-50$ lat & 6 & 15,8 \\
\hline powyżej 50 lat & 9 & 23,7 \\
\hline razem & 38 & 100,0 \\
\hline
\end{tabular}

Źródło: wynik badań własnych

Badanych podzielono na cztery grupy wiekowe: 22-35 lat, 36-45 lat, 46-50 lat oraz powyżej 50 lat. Najliczniejszą grupę stanowili badani w wieku 22-35 lat - 14 osób (36,8\%), najmniej liczną w wieku 46-50 lat - 6 osób $(15,8 \%)$.

Tabela 2. Wykształcenie badanych.

\begin{tabular}{|l|l|l|}
\hline wykształcenie & N & $\%$ \\
\hline liceum medyczne & 11 & 28,9 \\
\hline studium medyczne & 4 & 10,5 \\
\hline licencjat pielęgniarstwa & 10 & 26,3 \\
\hline magister pielęgniarstwa & 13 & 34,2 \\
\hline razem & 38 & 100,0 \\
\hline
\end{tabular}

Źródło: wynik badań własnych 
Wśród badanych, najwięcej osób uzyskało tytuł magistra pielęgniarstwa - 13 osób (34,2\%). Najmniejszą grupę badanych stanowili absolwenci studium medycznego - 4 osoby $(10,5 \%)$.

Tabela 3. Miejsce zamieszkania badanych.

\begin{tabular}{|l|l|l|}
\hline miejsce zamieszkania & N & $\%$ \\
\hline wieś & 9 & 23,7 \\
\hline miasto & 29 & 76,3 \\
\hline razem & 38 & 100,0 \\
\hline
\end{tabular}

Źródło: wynik badań własnych

Analizując wyniki z miasta pochodziło - 29 osób (76,3\%), natomiast mieszkanie na wsi zdeklarowało 9 osób $(23,7 \%)$.

Tabela 4. Najistotniejsze czynniki stresogenne w pracy pielęgniarki/ pielęgniarza w opinii badanych.

\begin{tabular}{|l|l|l|}
\hline czynnik & N & $\%$ \\
\hline bezradność w obliczu cierpienia & 14 & 13,9 \\
\hline brak poprawy stanu zdrowia pacjenta & 14 & 13,9 \\
\hline roszczeniowość pacjentów & 25 & 24,8 \\
\hline śmierć pacjentów & 24 & 23,8 \\
\hline poczucie odpowiedzialności za drugą osobę & 24 & 23,8 \\
\hline razem & 101 & 100,0 \\
\hline
\end{tabular}

Źródło: wynik badań własnych 
Odpowiadając na pytanie o najważniejsze czynniki stresogenne w pracy pielęgniarki/ pielęgniarza, badani zaznaczali po kilka stwierdzeń. Najwięcej respondentów zaznaczyło roszczeniowość pacjentów - 25 osób $(24,8 \%)$ oraz w takim samym stopniu na śmierć pacjentów i poczucie odpowiedzialności za drugą osobę - po 24 osoby (po 23,8\%). Najmniej badanych wskazało na bezradność w obliczu cierpienia i brak poprawy stanu zdrowia pacjenta - po 14 osób (po13,9\%).

Tabela 5. Czynniki stanowiące przypuszczalne źródła powstania stresu oraz wypalenia zawodowego w opinii badanych.

\begin{tabular}{|l|l|l|}
\hline czynnik & N & $\%$ \\
\hline zła organizacja pracy & 31 & 19,6 \\
\hline duża odpowiedzialność za innych & 26 & 16,5 \\
\hline praca zmianowa & 20 & 12,7 \\
\hline $\begin{array}{l}\text { poczucie nieadekwatności wynagrodzenia do } \\
\text { wykonywanej pracy }\end{array}$ & 31 & 19,6 \\
\hline konieczność pełnienia dyżurów nocnych i świątecznych & 19 & 12,0 \\
\hline zła atmosfera w pracy & 31 & 19,6 \\
\hline razem & $\begin{array}{l}15 \\
8\end{array}$ & $\begin{array}{l}100, \\
0\end{array}$ \\
\hline
\end{tabular}

Źródło: wynik badań własnych

$\mathrm{Na}$ oddziale zabiegowym, najwięcej badanych podało wśród czynników stanowiących przypuszczalne źródło stresu i wypalenia zawodowego: złą organizację pracy, poczucie nieadekwatności wynagrodzenia do wykonywanej pracy oraz złą atmosferę w pracy - 
po 31 osób (po 19,6\%). Najmniej wskazało na konieczność pełnienia dyżurów nocnych i świątecznych - 19 osób $(12,0 \%)$.

Tabela 6. Średnie wyniki strategii radzenia sobie ze stresem przez badanych.

\begin{tabular}{|l|l|l|}
\hline strategia & średnia & SD \\
\hline aktywne radzenie sobie & 2,00 & 0,63 \\
\hline planowanie & 1,78 & 0,60 \\
\hline pozytywne przewartościowanie & 1,79 & 0,63 \\
\hline akceptacja & 1,80 & 0,64 \\
\hline poczucie humoru & 0,80 & 0,62 \\
\hline zwrot ku religii & 0,68 & 0,78 \\
\hline poszukiwanie wsparcia emocjonalnego & 1,72 & 0,78 \\
\hline poszukiwanie wsparcia instrumentalnego & 1,50 & 0,71 \\
\hline zajmowanie się czymś innym & 1,82 & 0,66 \\
\hline zaprzeczanie & 0,75 & 0,62 \\
\hline wyładowanie & 1,30 & 0,74 \\
\hline zażywanie substancji psychoaktywnych & 0,28 & 0,54 \\
\hline zaprzestanie działań & 0,72 & 0,60 \\
\hline obwinianie siebie & 1,07 & 0,74 \\
\hline Źrodto: wynik bactá wasnych & & \\
\hline
\end{tabular}

Źródło: wynik badań własnych 
Respondenci $\mathrm{z}$ oddziału zabiegowego $\mathrm{w}$ radzeniu sobie ze stresem stosowali najczęściej takie strategie jak: aktywne radzenie sobie- 2,0 punkty, zajmowani się czymś innym - 1,82 punktu, akcentacja - 1,80 punktu, pozytywne przewartościowanie i rozwój 1,79 punktu oraz planowanie - 1,78 punktu. W najmniejszym stopniu badani wskazywali zaprzeczanie - 0,75 punktu, zaprzestanie działań 0,72 punktu, zwrot ku religii - 0,68 punktu oraz zażywanie substancji psychoaktywnych $-0,28$ punktu.

Tabela 7. Średnie stylów radzenia sobie ze stresem.

\begin{tabular}{|l|l|l|}
\hline styl (czynnik) & Średnia & SD \\
\hline aktywne radzenie sobie & 1,86 & 0,45 \\
\hline bezradność & 0,69 & 0,39 \\
\hline poszukiwanie wsparcia & 1,61 & 0,67 \\
\hline zachowania unikowe & 1,29 & 0,43 \\
\hline zwrot ku religii & 0,68 & 0,78 \\
\hline akceptacja & 1,80 & 0,64 \\
\hline poczucie humoru & 0,80 & 0,62 \\
\hline
\end{tabular}

Źródło: wynik badań własnych

Respondenci pracujący na oddziale zabiegowym stosowali najczęściej takie style radzenie sobie ze stresem jak: aktywne radzenie sobie - 1,86 punktu i akceptacje - 1,8 punktu. Najmniej osób wybierało bezradność - 0,69 punktu oraz zwrot ku religii - 0,68 punktu. 


\section{Dyskusja}

Pielęgniarki stanowią najbardziej liczną grupę zawodową wśród pracowników medycznych i odgrywają dużą rolę w opiece nad pacjentami. Jednak praca pielęgniarki wiąże się też $\mathrm{z}$ narażeniem na stres [13].Przyjmuje się, iż środowisko pracy pielęgniarek jest związane z dużym narażeniem na działanie czynników stresogennych, wynika to przede wszystkim z dużej odpowiedzialności za życie ludzie $[12,13]$.

Stres zawodowy, według Państwowej Inspekcji Pracy, występuje wtedy, gdy „(...) pracownicy doświadczają dyskomfortu psychicznego związanego z warunkami bądź wymaganiami pracy, w sytuacji, kiedy przekraczają one ich możliwości" [14]. Charakterystyczny rodzaj stresu, który występuje w przypadku pracy pielęgniarskiej jest najczęściej wynikiem bezpośredniego kontaktu z innym człowiekiem - pacjentem, który często cierpi i wymaga udzielenia bezzwłocznej pomocy, oczekując jednocześnie opieki indywidualnej i wsparcia psychologicznego [12].

Celem aktualnej pracy była analiza strategii i sposobów radzenia sobie ze stresem $\mathrm{w}$ grupie pielęgniarek pracujących na oddziałach zabiegowych.

W badaniach własnych najbardziej istotne czynniki stresogenne $\mathrm{W}$ pracy pielęgniarskiej według ankietowanych pracujących na oddziale zabiegowym to: roszczeniowość pacjentów, śmierć pacjenta, poczucie odpowiedzialności za drugą osobę. Respondenci, podali, że źródła stresu zawodowego to przede wszystkim wynagrodzenie nieadekwatne do pracy, zła organizacja i zła atmosfera w pracy.

Te same czynniki i źródła stresu powtarzają się również w wynikach badań innych autorów. Kędra i Sanak [10] odnotowują że główną przyczyną stresu zawodowego, według 80\% badanych pielęgniarek, są warunki płacowe. Pozostałe dominujące czynniki powodujące stres badanych to nadmiar dokumentacji, 
odpowiedzialność za życie i zdrowie pacjenta, niezadowolenie i pretensje pacjentów i ich rodzin, praca zmianowa oraz dyżury nocne i świąteczne.

W badaniach własnych ze względu na poziom istotności $(p<0,05)$ nie odnotowano istotnej statystycznie różnicy pomiędzy miejscem zatrudnienia a strategiami i stylami radzenia sobie ze stresem. Respondenci stosowali najczęściej następujące strategie radzenia sobie ze stresem: aktywne radzenie sobie- 2,0 punkty, zajmowani się czymś innym - 1,82 punktu, akcentacja - 1,80 punktu, pozytywne przewartościowanie i rozwój - 1,79 punktu oraz planowanie - 1,78 punktu. W najmniejszym stopniu wybierali z kolei: zaprzeczanie - 0,75 punktu, zaprzestanie działań - 0,72 punktu, zwrot ku religii - 0,68 punktu oraz zażywanie substancji psychoaktywnych 0,28 punktu. Pielęgniarki/pielęgniarze stosowały najczęściej następujące style radzenia sobie ze stresem: aktywne radzenie sobie 1,86 punktu i akceptacja - 1,8 punktu. W najmniejszym stopniu wybierali z kolei: bezradność - 0,69 punktu oraz zwrot ku religii - 0,68 punktu.

W swojej sytuacji zawodowej pielęgniarki, częściej niż przedstawiciele innych profesji, mogą być narażone na destrukcyjne działanie negatywnych emocji i stresu. W dotychczasowym modelu kształcenia pielęgniarek $\mathrm{w}$ Polsce umiejętności radzenia sobie w trudnych sytuacjach nie były rozwijane, zwłaszcza na poziomie przygotowania praktycznego. Można zatem przypuszczać, że przedstawiciele personelu pielęgniarskiego stosują co najwyżej zwyczajowe metody radzenia sobie ze stresem w pracy [15].

Żuralska i wsp. [16] przedstawili w swej pracy trzy strategie radzenia sobie ze stresem: styl skoncentrowany na zadaniu (podejmowanie wysiłku poznawczego), styl skoncentrowany na emocjach (koncentrowanie się na własnych reakcjach emocjonalnych) i styl skoncentrowany na unikaniu (niemyślenie o problemie). Autorzy podkreślają, że osoba posiadająca więcej różnorodnych strategii radzenia sobie ze stresem, może je bardziej 
elastycznie i skutecznie wykorzystywać. Rola stylu skoncentrowanego na zadaniu została podkreślona w rozumieniu dobrostanu, który sprzyja rozwojowi subiektywnego stanu zdrowia.

W badaniach Nyklewicza i Krajewskiej-Kułak [17], które objęły 100 studentów pielęgniarstwa $\mathrm{z}$ Białegostoku, zarejestrowano zadaniową reakcję na stres u $22 \% \mathrm{z}$ nich. Styl skoncentrowany na emocjach odnotowano u 9\% pielęgniarek, zaś styl skoncentrowany na unikaniu - również u 9\% badanych. Wśród pozostałych $60 \%$ pielęgniarek żaden z tych stylów nie był dominujący.

\section{Wnioski}

1. Według pielęgniarek/pielęgniarzy roszczeniowość pacjentów, śmierć pacjentów oraz poczucie odpowiedzialności za drugą osobę stanowią główne czynniki stresogenne w pracy zawodowej.

2. Czynnikami stanowiącymi przypuszczalne źródła powstania stresu oraz wypalenia zawodowego zdecydowanie są zła organizacja pracy, zła atmosfera w pracy oraz poczucie nieadekwatności wynagrodzenia do wykonywanej pracy.

3. Zatrudnienie $w$ oddziałach zabiegowych nie miało istotnego wpływu na wybór strategii i stylów radzenia sobie ze stresem przez pielęgniarki/pielęgniarzy.

\section{Zalecenia dla praktyki pielęgniarskiej}

Dla przeciwdziałania stresowi w grupie zawodowej pielęgniarek/pielęgniarzy należy rozwijać i wzmacniać umiejętności dotyczące rozwiązywania konfliktów, poprawy relacji interpersonalnych $\mathrm{w}$ zespole terapeutycznym oraz doskonalić zasady efektywnej komunikacji i zarządzania czasem pracy, jak również zwrócić szczególną uwagę na kształtowanie i modyfikowanie 
asertywnego modelu radzenia sobie ze stresem oraz trudnym pacjentem.

Powyższe działania wpłyną pozytywnie na poprawę jakości świadczonej opieki pielęgniarskiej i komfort pracy pielęgniarki.

\section{Bibliografia / Bibliography:}

1. Bartkowiak G.: Człowiek w pracy. Od stresu do sukcesu. Polskie Wydawnictwo Ekonomiczne, Warszawa 2009; 13-20.

2. Borys B., Majkowicz M.: Psychologia w medycynie. Wyd. AMG, Gdańsk 2006;67-108,160-196.

3. Terelak J. F.: Człowiek i stres. Wyd. Branta, Warszawa 2008; 210,99-108,152-160,229-246,289-333.

4. Nowak - Starz G., Kozak B., Zdziebło K.: Wpływ stresu związanego z pracą zawodową na występowanie zespołu wypalenia zawodowego u pielęgniarek pracujących w oddziałach zabiegowych i zachowawczych. Studia Medyczne 2013; 29(1): 15-21.

5. Łodzińska J.: Seminare- poszukiwania naukowe. Stres zawodowy narastającym zjawiskiem $\mathrm{w}$ miejscu pracy. Wyd. Towarzystwo Naukowe Franciszka Salezego , Kraków 2010; 162-170.

6. Waszkowska M., Merecz D., Drabek M.: Programy prewencji stresu zawodowego - strategie, techniki, ocena skuteczności. Medycyna Pracy 2009; 60(6):523-529.

7. Tartas M., Derewicz G., Walkiewicz M., Budziński W.: Źródła stresu zawodowego $\mathrm{w}$ pracy pielęgniarek zatrudnionych $\mathrm{w}$ oddziałach o dużym obciążeniu fizycznym i psychicznym - hospicjum oraz chirurgii ogólnej. Ann. Acad. Med. Gedan., Gdańsk 2009; 145-153.

8. Wzorek A.: Porównanie przyczyn stresu wśród pielęgniarek pracujących na oddziałach o różnej specyfice. Studia Medyczne 2008; 11:33-37. 
9. Freudenberger H. J.: Staff Burnout. Journal of Social Issues,1974 30 (1): 159-165.

10. Kędra E, Sanak K.: Stres i wypalenie zawodowe w pracy pielęgniarek. Piel. Zdr. Publ. 2013; 3 (2): 119-132.

11. Sęk H.: Wypalenie zawodowe. PWN, Warszawa 2004; 84-96,182187.

12. Wilczek-Rużyczka E.: Wypalenie zawodowe a empatia u lekarzy i pielęgniarek. Wyd. Uniwersytetu Jagiellońskiego 2008; 46-49.

13. Kędra E, Nowocień M.: Czynniki stresogenne a ryzyko wypalenia zawodowego w pracy pielęgniarek. Pielęgniarstwo Polskie 2015; 3(57): 293-306.

14. Stres w miejscu pracy- stan prawny, przeciwdziałanie oraz działania związków zawodowych http://www.opzz.org.pl/documents/707532/707723/publikacja+s tres.pdf [dostęp: 08.06.2017].

15. Nyklewicz W, Krajewska-Kułak E.: Śmierć a emocje pielęgniarek doniesienie wstępne. Problemy Pielęgniarstwa 2008; 16 (3): 248254.

16. Żuralska R, Mziray M, Postrożny D, Domagała P.: Poczucie własnej skuteczności a style radzenia sobie z sytuacją trudną u pielęgniarek pracujących z chorym umierającym. Przedsiębiorczość i Zarządzanie 2014; XV (12,Część II): 131-141.

17. Skorupska-Król A, Szabla A, Bodys-Cupak I.: Opinie pielęgniarek na temat czynników stresogennych związanych z ich środowiskiem pracy. Pielęgniarstwo XXI wieku 2014; 1(46): 23-26. 